\title{
PENGEMBANGAN ANIMASI 3D BERBASIS VIRTUAL REALITY PADA MEDIA PROMOSI PERUMAHAN CLUSTER GREEN BIDURI
}

\author{
Anita Soraya ${ }^{1}$, Hamidiilah Ajie, ST., MT ${ }^{2}$, Vina Oktaviani, MT $^{3}$ \\ ${ }^{1}$ Mahasiswa Prodi PendidikanTeknik Informatika dan Komputer, Teknik Elektro, FT - UNJ \\ ${ }^{2,3}$ Dosen Prodi Pendidikan Teknik Informatika dan Komputer, Teknik Elektro, FT - UNJ \\ ${ }^{1}$ sorayaanita96@gmail.com, ${ }^{2}$ hamidillah@yahoo.com, ${ }^{3}$ vina.oktaviani@unj.ac.id
}

\begin{abstract}
Abstrak
Green Biduri merupakan sebuah perumahan dengan sistem cluster yang terdapat di daerah Kranggan, Bekasi. Dalam melakukan pemasaran, Green Biduri mempunyai beberapa kendala. Salah satu kendala utama yang dihadapi adalah keterbatasan media promosi yang dapat menggambarkan secara jelas atau nyata mengenai produk perumahan yang dipromosikan. Penelitian ini bertujuan untuk mengembangkan animasi $3 D$ berbasis virtual reality sebagai media promosi. Metode penelitian yang digunakan adalah Metode Rekayasa Teknik dengan model MDLC (Multimedia Development Life Cycle). Tahapan penelitian yang dilakukan terdiri dari:1) konsep; 2) desain; 3) pengumpulan bahan; 4) pembuatan; 5) uji coba. Data yang digunakan didapatkan dari hasil observasi dan wawancara. Pengujian dilakukan kepada ahli materi, ahli media dan responden dengan melakukan validasi instrumen terlebih dahulu. Hasil pengujian dengan ahli materi 1. Kemudian hasil pengujian oleh ahli media 0.47 dan hasil pengujian responden 84\%. Berdasarkan hasil pengujian yang telah dilakukan, maka media promosi dapat dikategorikan "sangat efektif".
\end{abstract}

Kata kunci : Virtual Reality, Pengembangan, Media Promosi, Android

\section{Pendahuluan}

Strategi marketing yang baik menjadi ujung tombak kemajuan dan keberlangsungan bisnis. Strategi marketing tidak hanya sebatas peningkatan jumlah konsumen, tetapi juga terkait dengan penggunaan media promosi sebagai sarana untuk menarik minat konsumen. Green Biduri merupakan sebuah perumahan dengan sistem cluster yang terdapat di daerah Kranggan, Bekasi. Dalam melakukan pemasaran, Green Biduri mempunyai beberapa kendala. Menurut salah satu sales marketing Green Biduri salah satu kendala utama yang dihadapi adalah keterbatasan media promosi yang dapat menggambarkan secara jelas atau nyata mengenai produk perumahan yang dipromosikan. Dalam memasarkan perumahan, Green Biduri hanya menggunakan media promosi berupa media cetak, personal selling, dan promosi langsung. Penggunaan media brosur dan katalog (media dua dimensi) belum dirasa cukup mendeskripsikan tipe rumah, karakter bangunan secara lengkap baik desain eksterior maupun interiornya sedangkan faktor tersebut merupakan sebuah kebutuhan informasi mendasar bagi calon pengguna produk.

Penelitian dari Universitas Maryland, Amerika Serikat, berhasil menemukan bahwa virtual reality membantu orang mengingat informasi lebih baik dari sebelumnya. Penelitian ini melibatkan 40 peserta yang kebanyakan dari mereka merupakan mahasiswa Universitas Maryland yang tidak familiar dengan VR. Mereka dibagi dua grup. Satu grup melihat informasi lebih dulu menggunakan VR lalu ke dekstop. Sedangkan, grup lainnya melihat informasi dari desktop lalu menggunakan VR. Kedua kelompok menerima gambar orang terkenal termasuk Abraham Lincoln, Dalai Lama, dan Arnold Schwarzenegger. Kemudian, para peneliti membuat 'istana memori' dari wajah tersebut dengan menggunakan dua lokasi imajiner, yaitu ruang interior berukir istana dan pemandangan dari kota abad pertengahan. Bagi peserta dengan VR menghafal masing-masing gambar menggunakan gerakan tubuh mereka sedangkan desktop menggunakan mouse. Hasilnya, ada peningkatan sekitar 8,8 persen dari jawaban peserta yang menggunakan headset VR. Ini dapat dikatakan virtual reality dapat membuat seseorang lebih fokus. (Viva.co.id: 2018)

Berdasarkan latar belakang masalah yang ada, maka dilakukan penelitian dengan judul pengembangan animasi 3D berbasis virtual reality sebagai media promosi di perumahan Green Biduri sebagai media alternatif untuk mempromosikan perumahan tersebut.

Dengan aplikasi Virtual Reality ini calon pembeli dapat berinteraksi dengan melihat contoh bangunan rumah serta ruangan-ruangan tersebut dari segala penjuru. Informasi yang akan dihasilkan nanti akan sangat berguna bagi para calon pembeli, yaitu calon pembeli dapat mengetahui bagaiman gambaran real dari rumah yang ditawarkan mulai dari eksterior serta interiornya. 


\section{Dasar Teori}

\subsection{Virtual Reality}

Menurut Hillis (1999) virtual reality menyatukan dunia teknologi dan kemampuannya untuk mempresentasikan alam, dengan bidang yang luas dan tumpang tindih mengenai hubungan sosial dan makna. Sedangkan menurut John Vince (2004) virtual reality adalah tentang navigasi dan manipulasi lingkungan yang dihasilkan komputer tiga dimensi. Pengguna virtual reality dapat menavigasi dengan berjalan, berlari, atau bahkan terbang melalui lingkungan virtual dan menjelajahi sudut pandang yang tidak mungkin dilakukan di dunia nyata. Lingkungan virtual reality terkini umumnya menyajikan pengalaman visual yang ditampilkan pada sebuah layar komputer, tetapi beberapa simulasi virtual reality tingkat tinggi mengikutsertakan juga tambahan informasi hasil pengindraan mata melalui kacamata, suara melalui speaker/headseat, gerakan tangan melalui glove dan gerakan kaki menggunakan peralatan walker.

Beberapa implementasi aplikasi virtual reality, yaitu: 1) Manufaktur: pengujian rancangan, prototipe semu, analisis ergonomik, simulasi semu dalam perakitan, produksi dan pemeliharaan; 2) Arsitektur: perancangan gedung, simulasi bangunan; 3) Militer: pelatihan (pilot, astronot, pengemudi), simulasi peperangan; 4) Hiburan: museum virtual, permainan balap, simulasi pertempuran udara, taman virtual, simulasi ski.

\subsection{Software SketchUp}

SketchUp (sebelumnya Google Sketchup) adalah sebuah program komputer pemodelan 3D untuk berbagai macam aplikasi menggambar seperti arsitektur, desain interior, sipil dan teknik mesin, film, dan desain video game. SketchUp saat ini dimiliki oleh Perusahaan Trimble Navigation, yang merupakan perusahaan dalam pemetaan, survei, dan peralatan navigasi. SketchUp memiliki sebuah perpustakaan online yang terbuka dengan model 3D gratis (misalnya jendela, pintu, mobil) yang dinamakan 3D Warehouse, disana para pengguna dapat ikut berkontribusi memberikan model 3D buatannya. Program ini memiliki fungsi menggambar tata letak, fungsi rendering dengan "style" variabel yang berbeda, mendukung banyak "plug-in" program pihak ketiga yang tersedia dalam Extension Warehouse agar mampu beradaptasi format media lainnya memungkinkan penempatan model 3D langsung ke dalam Google Earth. (Wikipedia: 2016).

\subsection{Software Unity}

Software Unity Unity adalah program pembuat game cross-platform yang dikembangkan oleh Unity Technologies. Unity biasa digunakan untuk mengembangkan video games untuk PC, smartphone, website dan juga console. Unity 3D adalah sebuah game engine yang berbasis cross- platform. Unity dapat digunakan untuk membuat sebuah game yang bisa digunakan pada perangkat komputer, smartphone Android, iPhone, PS3, dan bahkan X-BOX. Sedangkan untuk pembuatan games online diperlukan sebuah plugin, yaitu Unity Web Player, sama halnya dengan Flash Player pada browser. Unity tidak dirancang untuk proses desain atau modeling, dikarenakan unity bukan tool untuk mendesain. Jika ingin mendesain, pergunakan 3D editor lain seperti 3dsmax atau Blender. Banyak hal yang bisa dilakukan dengan unity, ada fitur audio reverb zone, particle effect, dan sky box untuk menambahkan langit. Fitur scripting yang disediakan, mendukung 3 bahasa pemrograman, JavaScript, C\#, dan Boo.

\subsection{Kerangka Berpikir}

Dalam merancang sebuah produk media promosi berbasis virtual reality salah satu langkah yang perlu dilakukan adalah membuat rancangan produk. Yang mana pengembangan produk terdapat beberapa tahapan. Tahapan yang digunakan untuk penelitian ini yaitu menggunakan model pengembangan produk Multimedia Development Life Cycle (MDLC). Model ini dikembangkan oleh Luther yang dimodifikasi oleh Sutopo (2012: 128).. Kerangka berpikir media promosi berbasis virtual reality ditunjukan pada Gambar 2.4.

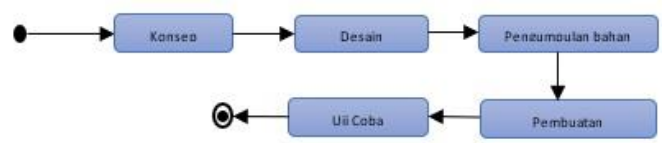

\section{Metodologi}

\subsection{Konsep}

Tujuan Pembuatan media promosi ini untuk membantu seorang sales properti mempresentasikan sebuah rumah yang dijualnya dengan mengimplementasikan virtual reality sebagai fitur untuk memvisualisasikan rumah. Dengan adanya fitur virtual reality yang dapat memperlihatkan rumah secara 3D, seorang sales dapat dengan mudah memperlihatkan bagian dan detil-detil rumah sehingga dapat tercitra dengan baik. Sasaran atau target dari media promosi ini adalah calon konsumen yang berusia 30 tahun keatas yang mempunyai keinginan untuk membeli rumah.

\subsection{Desain Perancangan Media Promosi}

Menurut Sutopo (2003:33) tahap desain adalah membuat spesifikasi secara rinci mengenai arsitektur proyek, gaya, dan kebutuhan material untuk proyek. Pada perancangan media promosi berbasis virtual reality ini menggunakan storyboard.

\subsection{Pengumpulan Bahan}

Tahap pengumpulan bahan yang digunakan dalam pembuatan media promosi berbasis virtual reality untuk perumahan Green Biduri seperti konten materi, gambar, serta animasi 3D. Pada tahap ini 
mulai digunakan software SketchUp 2018 Pro untuk membuat bangunan 3D rumah tipe 64 serta properti pendukung yang terdapat didalam interior seperti: kasur, sofa, lemari dan kicthen set.

\subsection{Penbuatan Bahan}

Tahap pembuatan dari bahan-bahan yang telah terkumpul berdasarkan perancangan yang telah disusun pada tahap desain, yaitu berdasarkan storyboard. Pada tahap pembuatan ini bahan-bahan yang telah dikumpulkan selanjutnya dirangkai dengan menggunanakan aplikasi pengolah animasi yaitu Unity.

\subsection{Uji Coba Produk}

Tahap testing (pengujian) dilakukan setelah menyelesaikan tahap pembuatan (assembly) dengan menjalankan aplikasi/program dan melihatnya apakah ada kesalahan atau tidak. Pada tahap testing terdapat 2 tahap dalam pengujiannya, yaitu Tahap Alpha dan Tahap Beta. Tahap pengujian alpha (alpha test) adalah tahap pengujian yang pengujiannya dilakukan oleh pembuat atau lingkungan pembuatnya sendiri, pengujian ini melibatkan ahli media dan ahli materi sebagai penguji yang menilai apakah media promosi berbasis virtual reality sudah layak atau belum untuk diujikan kepada responden. Setelah lolos dari pengujian alpha, pengujian beta yang melibatkan responden atau pengguna akhir akan dilakukan (Binanto, 2010:263). Pada penelitian ini pengujian responden melibatkan masyarakat umum yang berusia 30 tahun keatas yang mempunyai keinginan untuk membeli sebuah rumah.

\section{Hasil Penelitian}

Proses pengembangan animasi 3D berbasis virtual reality sebagai media promosi di Perumahan Cluster Green Biduri dilakukan dengan menggunakan metode Rekayasa Teknik dengan model pengembangan MDLC (Multimedia Development Life Cycle). Model MDLC memiliki 5 tahapan, yaitu concept, design, material collecting, assembly dan testing. Observasi dilakukan diawal penelitian tujuannya untuk mengetahui informasi tentang perumahan tersebut dengan benar. Tahap penelitian awal dilakukan dengan melakukan wawancara terhadap salah satu sales marketing Perumahan Green Biduri. Setelah di dapat data, kemudian disimpulkan bahwa menurut sales marketing Perumahan Green Biduri tersebut, bahwa kurangnya media yang memberikan visual detail seperti 3D untuk menjelaskan bagian-bagian rumah yang ada.

Pengembangan media promosi berbasis virtual reality ini dibuat dengan menggunakan aplikasi SketchUp 2018 Pro dan Unity. Media ini dibuat untuk pengguna Android. Instrumen uji ahli media, ahli materi, dan responden divalidasi oleh beberapa dosen yang berada di prodi Pendidikan Teknik Informatika dan Komputer Universitas Negeri Jakarta. Setelah produk selesai, dilakukan uji kelayakan oleh ahli materi, dan ahli media. Berdasarkan hasil uji kelayakan ahli materi medapat hasil 1 dengan kategori "validitas tinggi". Sedangkan hasil uji kelayakan oleh ahli media mendapat hasil 0,47 dengan kategori "validitas sedang". Tahap selanjutnya dilakukan uji efektifitas terhadap responden yang berjumlah 20 orang yang mempunyai kualifikasi usia diatas 30 tahun. Hasil uji efektifitas mendapatkan nilai berupa persentase sebesar $84 \%$. Mengacu pada Tabel 3.10 Persentase Skor Akhir Skala Likert. Maka dapat disimpulkan bahwa media promosi berbasis virtual reality dikategorikan sebagai "sangat efektif" untuk dijadikan sebagai media promosi.

\section{Kesimpulan dan Saran}

Dari hasil penelitian yang telah diimplementasikan, maka dapat ditarik kesimpulan bahwa hasil dari penelitian pengembangan ini adalah sebuah produk, yaitu aplikasi Android berbasis virtual reality sebagai media promosi pada Perumahan Cluster Green Biduri. Proses pengembangan media promosi menggunakan metode pengembangan Rekayasa Teknik. Sedangkan model pengembangan produk yang digunakan yaitu: MDLC (Multimedia Development Life Cycle) dimana metode ini memiliki 5 tahapan, yaitu concept, design, material collecting, assembly dan testing. Pengujian dilakukan kepada 2 orang ahli materi, 2 orang ahli media dan 20 responden. Hasil pengujian dengan ahli materi mendapat hasil validitas 1 . Kemudian hasil pengujian dengan ahli media mendapat validitas 0.47 . Sedangkan persentase hasil uji responden mendapat hasil $84 \%$.

Berdasarkan pengujian fungsional menunjukkan bahwa aplikasi Android berbasis virtual reality telah berjalan dengan baik, dimana aplikasi dapat manampilkan model 3D rumah, dan secara interaktif calon pembeli rumah bisa masuk ke dalam melihat model 3D rumah serta melihat properti pendukung yang ada.

\section{Daftar Pustaka:}

Anonim.(2015).http://www.knightfrank.com/researc h/global-house-price-index-q1-2017-4736aspx. Diakses pada tanggal 18 April 2018.

Asyar, Rayandra. (2012). Kreatif Mengembangkan Media Pembelajaran. Jakarta: Referensi Jakarta.

Dandles Banjarnahor. 2016. Museum Berbasis Virtual Reality Untuk Mempromosikan Kebudayaan Sumatera Utara. e-Proceeding of Applied Science. 2(2): 733-740.

Firman Setiawan Riyadi. 2017. Aplikasi 3d Virtual Reality Sebagai Media Pengenalan Kampus Politeknik Negeri Indramayu Berbasis Mobile. Informatika dan Komputer. 2(2): 76-82.

Gazali, W., Ivan, M., Manik, N. I. 2013. Aplikasi Perubahan Citra 2D Menjadi 3D Dengan 
Metode Stereoscopic Anaglyph Berbasiskan Komputer. Jurnal Mat Stat. 13(1):1-7.

Hendryadi. 2017. Validitas Isi: Tahap Awal Pengembangan Kuesioner. Jurnal Riset Manajemen dan Bisnis (JRMB) Fakultas Ekonomi UNIAT. 2:169:178

Heri,Retnawati. (2016). Analisis Kuantitatif Instrumen Penelitian (Panduan Peneliti, Mahasiswa, dan Psikometrian). Yogyakarta: Parama Publishing.

Herry,Oscar.(2016)https://idseducation.com/articles/ memahami-lebih-dalam-pengertian-animasi-

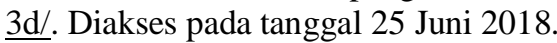

KBBI ([tahun tidak diketahui]). KBBI. Diakses pada 5 Mei 2018, dari KBBI: http://kbbi.web.id/promosi.

L. Evans, Denise \& Evans, William. (2007). The Complete Real Estate Encyclopedia. Amerika Serikat: McGraw-Hill.

Moejiono dkk, (1992). Stategi Belajar Mengajar, Jakarta: Departemen Pendidikan dan Kebudayaan Derektorat jenderal Pendidikan Tinggi Proyek Pembinaan Tenaga Pendidikan Nopembrian, G. A. \& Susanto P. (2014) Perangkat Lunak 3D Modeling Properti Sebagai Media Pemasaran Menggunakan Teknologi Augmented Reality Berbasis Android. Jurnal Proyek Akhir 3310114_LPKIA, 1-7.

Pressman, Roger S. (2002). Rekayasa Perangkat Lunak (Pendekatan Praktis). Terjemahan oleh Hermaningrum, LN. 2002. Yogyakarta: Andi.

Sugiyono. (2016). Metode Penelitian Kombinasi (Mixed Methods). Bandung: Alfabeta. 